811.163.41'282.2(497.11-12)

811.163.41'37

https://doi.org/10.18485/kij.2018.65.3_4.2

ТАЊА 3. МИЛОСАВЉЕВИЋ *

Оригинални научни рад

Институт за српски језик САНУ

Примљен: 05. 11. 2018.

Београд

Прихваћен: 15. 11. 2018.

\title{
СИНОНИМСКИ РЕД КАО ОДРАЗ ЛИНГВОКУЛТУРНИХ СПЕЦИФИЧНОСТИ ДИЈАЛЕКАТСКОГ ЛЕКСИЧКОГ СИСТЕМА*
}

\begin{abstract}
Актуелност предложене теме проистиче из тежње савремене словенске лингвистике ка систематизацији дијалекатске лексике, системском описивању лексичких јединица, интерпретирању њихових међусобних односа и екстраховању лингвокултурних специфичности дијалекатских система. Лексичка синонимија представља један од најпродуктивнијих механизама попуњавања одређених концепата на дијалекатској језичкој слици света и манифестује карактеристичне црте категоризације и концептуализације стварности конкретне дијалекатске језичке личности. Процес формирања синонимских редова у народним говорима укључује сликовито и емотивно преосмишљавање реалности, компоненте традиционалне културе колектива и његов наивни поглед на свет. Циљ рада је анализа многочланих синонимских редова којима је репрезентована језичка слика човека у говорима југоисточне Србије са аспекта когнитивне семантике и лингвокултурологије. Теоријске претпоставке проверићемо на примерима најбројнијих синонимских редова у антропографској лексици призренско-тимочког дијалекта српског језика. Пресек првих петнаест најбројнијих синонимских редова у категоријама квалификације и номинације мушких и женских лица у говорима југоисточне Србије потврђује тенденцију дијалекатске језичке личности да вербално обележи негативне људске особине. Укупна статистика негативних вербалних репрезентација показује да пет најбројнијих синонимских редова садржи следећа идентификациона семантичка обележја 'глуп' (257 лексичких ознака), 'лењ' (173), 'неуредан' (168), 'брбљив' (151),'непоуздан' (133). Многочлани синонимски редови профилишу друштвено пожељну слику човека, која је архетипски утиснута у свести човека са југоистока Србије као прототип у односу на који се припадници говорне заједнице процењују. За представнике југоисточних
\end{abstract}

*tanja77nis@gmail.com

** Овај рад настао је у оквиру пројекта „Дијалектолошка истраживања српског језичког простора" (ЕДБ 178020), који у целости финансира Министарство просвете, науке и технолошког развоја Републике Србије.

Радје у форми постер-реферата презентован на XVI Међународном конгресу слависта, одржаном у Београду 20-27. августа 2018. године. 
српских говора прототипичан мушкарац је интелигентан, радан, психички стабилан и поштен, а прототипична жена је честита, уредна, мудра и вредна.

Кључне речи: синонимски ред, дијалекатска језичка слика света, лингвокултурне специфичности, говори југоисточне Србије.

Основна тема рада јесте синонимски ред као начин репрезентације језичке слике човека и као одраз лингвокултурних специфичности дијалекатског лексичког система. ${ }^{1}$ Актуелност предложене теме проистиче из тежње савремене словенске лингвистике ка систематизацији дијалекатске лексике, системском описивању лексичких јединица, интерпретирању њихових међусобних односа и екстраховању лингвокултурних специфичности дијалекатских система. Полазећи од чињенице да синонимски односи представљају посебан модел интерпретације објективне стварности и да је лексичка синонимија један од најпродиктивнијих механизама попуњавања одређених концепата на језичкој слици света, у раду ће бити проверена хипотеза на који начин и у којој мери синонимски редови рефлектују специфичне језичке и културне црте и одсликавају менталитет дијалекатске личности и њен наивни поглед на свет. Многочлане синонимске редове проучавамо с когнитивносемантичког и лингвокултуролошког аспекта. Когнитивносемантички приступ обезбеђује издвајање интегралних и диференцијалних сема у значењима синонима, уочавање денотативних, сигнификативних и конотативних разлика, разоткривање значењских нијанси које се актуелизирају у испитиваним говорима и проучавање улоге синонимије у репрезентацији језичке слике света, нарочито дијалекатске језичке слике човека као њеног најкомплекснијег фрагмента. ${ }^{2}$ Когнитивистички приступ лексичко-семантичком проучавању синонимских редова подразумева реконструкцију читавог система представа, асоцијација и оцена носилаца дијалекта, а антропоцентричка парадигма у жижу научне пажње ставља човека који је истовремено и субјекат и објекат језичке слике света. Лингвокултуролошка анализа усмерена је на истраживање културног фона синонима, дешифровање културних кодова и препознавање црта менталитета говорника призренско-тимочке дијалекатске области.

Циљ рада је испитивање улоге синонимских редова у дијалекатској репрезентацији слике човека као централног фрагмента језичке слике света. Постављени циљ могуће је остварити реализацијом следећих задатака: издвајањем многочланих синонимских редова из семантичког поља 'човек', утврђивањем тематских сфера које се одликују активном синонимијим и идентификовањем

${ }^{1}$ „Синонимы не только несут в себе смысловубю нагрузку, но, объединяясь в группы слов, стремятся с наибольшей полнотой и глубиной демонстрировать представления об окружающем мире” (Хисамова-Хиснатулина 2016: 97).

2 Језичка слика човека у науци се интерпретира као језички одраз знања и представа човека о самоме себи, о својим особинама, стањима и деловању, о другим људима и међуљудским односима (Покровская 2008: 9). 
најзначајнијих когнитивносемантичких ознака слике човека на језичкој слици света призренско-тимочких говора. Поимање човека у свеукупности његовог телесног, духовног и друштвеног бића, вредновање естетских, карактерних и моралних особина личности и на основу субјективне оцене формирање колективног суда о пожељним, односно непожељним својствима и креирање представе о прототипу, утиснути су као фонски елементи у најдубљим слојевима семантичке структуре речи о човеку сакупљених у збирку под насловом Aнmропографски речник југоисточне Србије (Богдановић 2016). Лингвоантрополошки потенцијал тематског дијалекатског речника Н. Богдановића очигледан је у самом наслову, чију детерминанту антропографски аутор објашњава значењем „онај што описује човека”, а о природи грађе каже „оно што ми издвајамо за састав ове збирке тиче се непосредно човека као природног и социјалног бића" (Богдановић 2016: 5), са тежњом да овај фонд дијалекатске лексике посведочи „о човековом бивствовању на једном простору српске националне и језичке територије, о поимању његове суштине, о схватању његових физичких и психичких карактеристика, као и социјалне породице...” (Богдановић 2016: 7).

Хипотезу да је могуће реконструисати дијалекатску језичку слику човека на основу испитивања многочланих синонимских редова проверићемо у категоријама квалификације и номинације мушких и женских особа. Резултате анализе квантитативних вредности, састава и семантичке организације синонимских редова представићемо табеларно. У табели је дато петнаест најбројнијих редова синонима за три испитиване категорије.

Прилог 1. Најбројнији синонимски редови са архисемом 'човек' у говорима југоисточне Србије

\begin{tabular}{|l|l|l|}
\hline Квалификација & Номинација мушке особе & Номинација женске особе \\
\hline 'луд' (65) & 'глуп човек' (143) & 'бестидна жена' (121) \\
\hline 'глуп' (64) & 'лењ човек' (127) & 'неуредна жена' (60) \\
\hline 'обестан' (58) & 'непоуздан човек' (100) & 'глупа жена' (50) \\
\hline 'слаб' (57) & 'брбљив човек' (94) & 'лења жена' (46) \\
\hline 'мршав' (42) & 'обестан човек' (86) & 'зла жена' (44) \\
\hline 'неуредан' (41) & 'зао човек' (85) & 'брбљива жена' (40) \\
\hline 'хром' (30) & 'неуредан човек' (67) & 'непоуздана жена' (33) \\
\hline 'дебео' (29) & 'халапљив човек' (56) & 'мршава жена' (32) \\
\hline 'тврдоглав' (28) & 'мршав човек' (44) & 'халапљива жена' (29) \\
\hline
\end{tabular}




\begin{tabular}{|l|l|l|}
\hline $\begin{array}{l}\text { 'који је са теле- } \\
\text { сном маном' (27) }\end{array}$ & 'немиран човек' (44) & $\begin{array}{l}\text { 'жена са говорном } \\
\text { маном' (24) }\end{array}$ \\
\hline 'низак' (25) & 'хром човек' (43) & 'хрома жена' (23) \\
\hline 'рохав' (23) & 'низак човек' (42) & 'чупава жена' (23) \\
\hline 'брбљив' (21) & 'луд човек' (41) & 'луда жена' (21) \\
\hline 'халапљив' (21) & 'шкрт човек' (41) & 'обесна жена' (21) \\
\hline 'чупав' (20) & 'сиромашан човек' (40) & 'дебела жена' (21) \\
\hline
\end{tabular}

Заједнички именитељи репрезената јесу денотативна компонента високог ранга 'човек' и компонента објективне оцене 'негативна особина'. Колектив перципира типичне психичке или физичке црте као доминантна својства личности, и, процењујући их у односу на прототип, креира лексичку ознаку у чији садржај уноси свој вредносни суд. Стога, језичке јединице овога типа садрже субјективно-аксиолошке значењске елементе, који чине конотативни макроплан њихове семантичке структуре. Сет субјективних семантичких чинилаца пуни денотативно значење лексема емотивним и експресивним садржајем и нијансира га одређеним степеном експресивности и афективним тоналитетом. Доминанта синонимског реда експресивно је најнеутралнија, док се остали конституенти градативно распоређују према интензитету емотивно-експресивних компонената. Избор лексичке варијанте зависи од говорне ситуације и комуникативног циља. Неформални карактер колоквијалног дискурса дијалекатској језичкој личности омогућава слободнији језички израз и обезбеђује флексибилнија комуникациона средства, тако да носилац дијалекта бира синониме снажнијег интензитета и тоналитета да изрази свој став, суд, презир, негодовање према појави која се датом речју именује и на тај начин пројектује менталитет заједнице и њен наивни поглед на свет.

У класи 'особина' доминирају придевске лексеме којима се квалификују умно поремећена и умно ограничена особа, што показује да су интелектуална својства на врху вредносне скале у наивном поимању људских особина. Носиоци југоисточних српских говора лудило и глупост перципирају као најнепожељније црте личности, а когнитивносемантичка анализа синонима са идентификационим семантичким обележјима 'луд' и 'глуп' показала је да се на језичкој слици човека ове говорне зоне бистар ум сматра основном општељудском и индивидуалном вредношћу, те да је важан оријентир духовног и социјалног благостања. Лингвокултурне карактеристике очитавају се у концептуализацији менталних активности првенствено као значајног стожера здраве људске заједнице, а неретко се доводе у везу и са другим дисфункционалним особинама личности, као што су неурачунљивост, променљивост расположења, емоционална нестабилност, плаховитост, непромишљеност, односно са недостатком образовања, непросвећеношћу, социјалном учмалошћу, простотом, наивношћу, незрелошћу, 
несналажљивошћу. Појмовна слика о умним способностима формализује се у језичком изразу и рефлектује у сложеној семантичкој организацији вербалних ознака са идеографским вредностима 'луд' и 'глуп', које се у неким значењским сегментима преклапају или допуњују. Говорници уочавају да се губитак разума испољава у неколико ступњева, да лудило има различите појавне фазе - од блажег поремећаја, занесености, преко склоности ка психички нестабилном и незрелом понашању, до тежих облика душевног обољења, и та се колективна запажања на језичкој слици света манифестују бројним синонимским редом квалификатива градативно конституисаном према интезитету присуства негативне особине: бле́саст, лу́иякас, лу́иес, налу́дччав, налу́дњичав, намао́вичав, настра́ничав, нашаша́вичав, наша́шњичав, сулу́дничав, сулу́дњичав („помало луд”); бле́сав, вртогла́в, заву́тнут, нечь́везан, шалаба́в, ша́нтав, шумогла́в, шупљогла́в, шу́ждав („блесав, шашав, ћакнут, сулуд, незрео”); бр́љав, бр́љив, нека́светан, нечами́зан, неча́мушан, плиткоу́ман, слабоу́ман, слу́тан, а́лнут (,умно поремећен, луд"). Овом реду прикључују се придеви са интегрално-диференцијалном семом 'глуп' који у семантичком саставу садрже допунске елементе 'ћакнут, луцкаст, сулуд', који идеографски обједињују низак интелектуални капацитет и нерационалне облике понашања: буда́лес, недоака́лан, недозре́л, недосо́лен, недота́ван, недопра́вен, недоте́пан, залу́ван, зау́љкав. Заступљеност особине у мањој мери изражава се деминутивним придевским лексемама глу́nавчьк, глу́павшьк, лума́ес, набле́съичав, набуда́лес, наглу́пњичав, нашунта́вичав, поприглу́пюичав, про́стачьк, слу́нкав, слу́ткав („помало глуп”). Ка врху скале интензитета гравитирају експресивне ознаке бла́нтав, ту́mав, ц̧а́лав, иу́цав, штурогла́в, ýнкав, зау́лав, ми́mав, где их ситуира значење „приглуп, поприлично, подоста глуп". Јединице а́нтиван, глу́nав, недоту́nав, слу́ғав, неока́стрен, неоте́сан, ту́nав, у́лав, лу́ав, лу́мав, пли́јав, малоу́ман, маломо́зан, бле́нтав, заљи́пен, уту́цан, нека́светан реализују денотативни садржај 'умно ограничен', реферирајући на умно заосталу особу или особу која у одређеним ситуацијама показује особине недотупавости, при чему се актуелизује субјективно-аксиолошки план значења. У фокусу друштвене нетолеранције су мушке особе умањеног коефицијента интелигенције, за чију номинацију говорници југоисточне Србије располажу са чак сто четрдесет три пејоративне јединице: ájma, алта́вштина, аљь́ тина, а́љча, а́мза, а́nља, а́пша, бајова́н, балаву́p, ба́нsа, банsи́ка, ба́ико, безвезња́к, би́лмез, бла́јало, бле́нта, бле́саваџ, блесавшти́на, бле́ско, бле́соња, бле́шча, брљо́тина, бубуле́јштина, буда́ла, будали́на, будалинка, буда́лка, буда́лче, будалчи́на, бутнитрн, бьлва́н, глупавшти́на, глупа́н, глупа́ндер, глупари́на, глупе́рда, глу́пча, глу́пша, гъе́ияало, дудуле́ја, дупегла́вац, жу́љча, загуља́ра, загуљо́тина, залупа́јка, залупа́јко, заулаво́тина, ма́млаз, му́лча, неве́да, недознаво́тина, недоранима́јћа, недотльче́нко, недотль́чко, неотрепо́тина, оштура́тина, склика, сле́пча, сли́нча, смлато́тина, смо́тља, сулупи́на, су́ртук, тиква́н, тлиман, тлчни́к, токма́к, торла́к, тотоба́к, тулпузи́на, тупа́н, ту́паџија, ту́nча, ту́та, тута́вко, ту́тавштина, тутма́к, тутуба́ја, тутуба́к, тутуба́н, тутуле́ја, тутуме́, ту- 
тумра́к, ту́цฺало, ту́иฺмак, ту́ичман, туту́ниа, ту́имула, ћо́рћутук, ћу́вало, ћурту́к, ћуту́к, ћућула́јкан, шандр́тко, шо́ња, шо́n, шту́рча, шумогла́воња, шумогла́вча, шу́нта, шу́шља, шьшкь́н, ши́шља... У категорији женских номинација синонимски ред са идентификационим семантичким обележјем 'глупа женска особа' по броју чланова је на трећем месту са педесет вербалних ознака, што учвршћује водећу позицију ове људске особине на листи најнепожељнијих: алтави́иа, алтавшти́на, аљо́тина, будали́на, будали́нка, буда́личка, буда́лка, глупари́на, глупари́нка, глупа́ча, глупе́рда, до́ртула, дудуле́ја, заулаво́тина, зауљкаво́тина, лу́авка, луди́ја, малоу́мница, му́лка, му́тла, оштуро́тина, склика, смлато́тина, смо́тла, тиква́на, ту́тавица, тутуба́нка, тутуба́ча, ту́цмула,

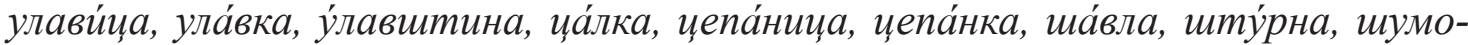
гла́вка... Из оквира представе о прототипичном друштвено прихватљивом понашању искачу оне црте личности које су у блиској вези са квалификацијама 'луд' и 'глуп'. Појмовном вредношћу 'обестан' обједињене су лексеме које у свом семском саставу експликују неку од следећих сема: 'необуздан', 'разуздан', 'плаховит', 'прек', 'ћудљив', 'срдљив', 'бесан', 'склон свађи', 'склон насиљу': а́љав, азди́сан, баксузе́с, беља́ван, беља́шан, бр́згав, бркоо́к, вадоо́чан, вадоо́члив, вапи́рес, вилења́в, гове́дљив, громоле́сан, др́згав, дујови́т, дунова́т, ду́лав, ду́рлес, дурлит, ду́рљав, дурнова́m, задо́рљив, заи́дљив, инатљи́в, мао́вит, надо́кљив, надо́кљичав, назо́рлив, назо́рњичав, нарављи́в, насти́ғичав, натла́пюичав, наца́к, наца́пит, нацапљи́в, наиа́пьичав, начо́рљив, недодр́гав, недр́гав, нездриго́сан, пли́јав, пр́ав, развр́зан, раздр́нчен, раздро́гав, саможи́ван, ср́чат, срчеви́т, у́збрљив, узо́рюичав, усампа́сен, чапорљи́в, чандр́тав, ча́љав, че́пав, чупуре́с, цандрљи́в, иоо́љав / азга́н, азганли́ја, азди́сник, аздисо́ја, аздисо́тина, аздишља́к, аздиса́нко, арамба́ша, арами́ја, аси́ја, бесни́к, бозгунийја, гороло́мник, громоле́сник, дурли́капа, ду́рлоња, ду́рља, ду́роња, ду́рча, задо́рица, задо́рко, задориијја, ка́вгалија, ка́вгачија, ке́не, костре́ш, костре́шко, наравли́ја, незгоди́ја, пакожийја, пустайја, сампа́с, саможи́вник, саможи́вњак, самсо́в, сва́ђаџија, та́баиија, табетли́ја, темеру́тин, иуиуле́ја / ацами́ка, бесна́ра, бесни́йа, бесну́ља, бешти́ја, закачо́љка, кавгачи́ка, костре́шка, подева́чка, саможи́вница, сампасу́љља, сва́ђаџика, чопрља́нка, цандрљи́вка... Комплексна семантичка структура ових синонимских редова предочава особености менталитета носилаца југоисточних српских говора, чијој моралној осуди подлежу оне људске особине које ремете социјалну стабилност заједнице. Необуздана, конфликтна нарав, неконтролисаност емоција, неприлагођеност понашајном обрасцу колектива препознати су као чиниоци нарушавања коректних друштвених односа, а црте личности које узрокују асоцијално владање појединца, обухваћене заједничким именитељем 'обестан' и језички маркиране са педесет осам придева и сто седам именица, класификоване су међу најнепожељније унутрашње карактеристике. Концепту обесне особе може се придружити појмовно близак, али интензитетом негативне афективности далеко слабији фрејм несташне особе, који укључује карактеристике личности као што су несташлук, непослушност, обешењаштво, које се прототипично везују за мушке особе: а́нтикрис, бе́дација, бе́дник, варта- 
ви́рта, весвесели́ја, ветропи́р, вирога́н, вра́г, враготе́р, вртоду́n, вртигу́з, гороле́сник, ђа́вол, Ђаво́лак, Ђаволе́сник, ђили́птер, ђи́лкош, недодр́ж, недодр́жља, нема́јмир, несми́рник, палама́ндра, сојтари́ја, суруци́ја, чапки́н, ци́рало, шаклама́н, шалаба́jзер, шаша́рма, шејта́н, шушуми́га... Периферијом когнитивносемантичке структуре концепт обесног човека задире у орбите концептуализације лудости, док је концепту 'глуп' блиско наивно поимање тврдоглавог човека. Категоријална дифузност пресликава се у подударању извесних сегмената значења вербалних ознака ових апстрактних изванјезичких појава. Одлике карактера као што су својеглавост, ограниченост, задртост, не искључују и компоненту 'недотупавост', али је обавезно не садрже. Ред синонима са надређеним семантичким знаком 'тврдоглав' одржава дистинктивну позицију на језичкој слици света и репрезентује намеру говорника да диференцира карактерне црте од интелектуалних својстава, при чему обе стварносне категорије процењује изразито неповољно и котира их високо на негативном полу вредносне скале: тврдогла́вес, баксузе́с, бандогла́вес, вапи́рес, главурда́нес, главуре́с, чапуре́с, бандогла́в, бе́словесан, бикови́т, дрвеногла́в, заба́кљив, за́дрт, зао́рљив, заче́пен, понастра́ничав, наче́пен, недока́жљьив, неразбо́рит, неразбо́рљив, нераза́бран, опо́рит, самовла́сан, самовла́сен, самово́љан, чапорљи́в, чапурљи́в, ии́јав... И у овом сегменту карактеризације уочава се изнијансираност поседовања особине. Облици са деминутивним суфиксом -ec(m) језички дочаравају заступљеност унутрашње карактеристике у мањој мери, односно склоност особе да у прототипичној ситуацији реагује својеглаво, да показује особине тврдоглавог човека. У клиширани сценарио уклапа се неразумна особа, која безразложно, упорно остаје при своме, што прераста у доминантно психичко својство, на основу којег личност бива карактерно маркирана и језички квалификована од стране социјума. Говорници призренско-тимочке дијалекатске области изражену тврдоглавост најчешће повезују са умном ограниченошћу, а у везу са сниженим коефицијентом интелигенције доводе и неуредност, аљкавост, физичку запуштеност. Брига о спољашњем изгледу, према схватању носилаца народних говора, у корелацији је са менталним развојем, чистоћа лица, тела, одеће еквивалентна је бистрини ума и чистоти духа. Свест о значају личне хигијене и спољашње уредности високо је развијена у југоисточним српским крајевима, о чему сведочи бројност придева и именица за денотацију неуредне особе и снажно испољена конотативна димензија њиховог значења: а́љкав, а́јтав, ајто́сан, ásав, влачопе́тав, га́латан, галатљи́в, др́пав, дри́шав, дри́шљав, дро́ндав, дро́њав, дро́њес, дро́пљав, дропљи́в, др́тав, жва́кав, жми́кав, засмакља́вен, ка́страв, мр́шкав, му́сав, му́сес, мь́шкав, неаљи́в, не́мит, о́љав, па́риав, пр́чав, скапо́сан, сма́кљав, смакљо́сан, смандро́сан, сопа́сан, уа́чкан, чо́лпав, чо́лтав, чо́рљав, иља́мпав, итро́кав / ásькаваи, а́љкавко, а́љавштина, алтоов, а́љча, влачопе́тина, влачопе́тоња, дри́паи, дри́nља, дри́пша, дри́шља, дро́љча, дро́љша, дро́ња, дро́њча, дро́пча, љо́nча, љо́nа, љо́пша, развлечо́тина, распара́нда, сма́кља, смакља́вко, смакља́н, смакљо́ч, смакно́тина, штро́кавштина, штрокља́н, штро́кча / áљавица, а́љка, а́љкавица, а́љкавка, арамза́да, бу́ниула, дри́пла, др́љка, др́љна, дрља́ча, др́нда, 
дро́ља, дро́nла, дро́nља, дро́nна, др́nла, др́nна, ђубришта́рка, жва́кна, сма́кла, сма́кљавка, смакља́на, смакно́тина, смр́дла, смра́дла, смрдљи́вка, смрдљу́га, смр́дна, штто́кла, штро́кна... Фрагмент неуредног човека, поред наведене појмовно-вербалне репрезентације укључује и чупаву и рохаву особу, које су на језичкој слици човека манифестоване богатим синонимским редовима: чи́nав, чи́nес, рашчу́мен, чи́мав, чу́мљав, бућогла́вес, гргу́рав, гр́чав, гр́кав, ду́рмес, ђу́мес, ко́сат, ко́смат, космура́т, котруљи́в, ку́драв, ску́бав, сми́кљав, тр́шав, тр́шљав..., „чупав”; ро́шав, белодро́бас, бубуља́в, бубуља́с, бубуљи́чав, вр́гав, гу́кав, жь́мбав, квр́гав, ко́чав, ко́чкав, кра́став, лу́нћав, лу́њав, наж́́мбав, пр́шав, ушљьа́мен, ша́нтав, ша́нтив, шантиња́в, ша́ргав, шко́бав, шо́ндрав..., „рохав”. Неуредност косе (разбарушеност, рашчупаност, замршеност, косматост) и рохавост лица (оспичавост, бубуљичавост, богињавост) спољашње су карактеристике личности које уобличавају и заокружују концепт човекове спољшњости и доказују да се ове особине конципирају као трајно психо-физичко стање човека.

Запажену позицију у концептуализацији телесних особина имају слабост и мршавост. Ове две категорије физичког стања човека у свести дијалекатске језичке личности нису јасно издиференциране, јер се обе поимају као одраз лошег здравља. Мала физичка снага, нејаки телесни састав, болешљивост, изнемоглост, исцрпљеност, онемоћалост од болести идеографски су знаци садржани у значењској структури придева са надређеним елементом 'слаб', који граде педесетседмочлани синонимски ред: сла́б, слабоду́шан, слаботеле́сан, слабужња́в, слабуна́в, а́липав, антиља́в, бо́лан, болежљи́в, бо́лесан, болешљи́в, болиња́в, болишња́в, больи́кав, болужња́в, болуња́в, бо́љњав, изнемо́гал, изњу́рен, исииибрен, испи́ен, исиибри́л, ичамре́л, ка́бав, ка́баван, кља́кав, кљо́кав, лавуња́в, ли́пав, малока́ван, малокр́ван, маражљи́в, маразљи́в, метиља́в, ми́жав, мр́ледан, нака́жљљив, неди́гав, неди́гљав, оплзал, орону́л, скапо́сан, скр́ан, скљо́кан, скр́кан, смо́љав, супетљи́в, супетљи́чав, ћи́шкав, чу́ркав, чурукљи́в... Наивне представе о слабости тела потенцијално укључују обележје 'мршав', а стереотип да су неухрањене особе најчешће и болесне или болешљиве посебно се очитава у семантичком садржају лексичких ознака са доминантном семом 'мршав': мр́шав, су́в, мршуља́в, су́вачьк, су́вњичав, пи́жав, пи́жљав, пи́кљав, пла́тичас, спе́кав, спекљо́сан, а́ветан, ви́жљив, ви́жљас, ви́лтрес, ви́так, ви́ткас, ви́икес, гр́чав, жго́љав, жо́љав, здрпљо́сан, кочтељи́в, коштиља́в, угло́бен, ции́брав,

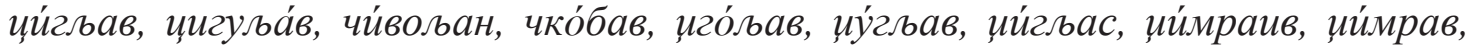
ши́ьвав, шко́бав, шко́ндрав, шпирто́сан, шти́кљав, шти́љав / а́вет, ву́дало, гр́чља, гу́ља, жвоњь́к, жго́ља, жго́љча, ко́ждер, кочте́љко, мриља́к, мршоти́ја, пи́жа, пи́жљьа, пи́кља, пи́кљаваи, пи́кља́вко, иииброња... / гу́љка, жго́љна, кље́штавица, кљештура́ча, кождеру́ља, ко́жла, ко́жљь, коште́љка, коштиља́вка, кошти́љка, мршо́јла, мршоти́ја, мршто́љка, ска́пна, спе́кла... За говорнике са овог подручја неухрањеност је непожељнија телесна особина од гојазности, иако оба физичка стања привлаче пажњу дијалекатске језичке личности. Недовољна ухрањеност повезује се са лошим здрављем, док се дебљина доводи у везу са психичком категоријом халапљивости. Одступање од прототипичне 
међувредности у оба правца језички је показатељ односа колектива према референтима којима се негативна својства приписују, при чему се естетска компонента неутралише, а у први план избија стереотипно уверење да је спољашњи изглед одраз здравља и унутрашњег стања. Наивно запажање корелације између прекомерне телесне тежине и грамзивости, појмовно прожимање негативних полова две концептосфере и квантитет вербалних ознака за дате психо-физичке карактеристике специфичности су призренско-тимочке језичке слике човека. У семантичкој организацији придева којима се описује дебела особа: ало́сан, бумбула́ес, бумбула́јас, бумбура́т, бумбуре́с, гма́чес, гме́чес, гојешљи́в, дебељу́шас, ду́ндес, мешина́m, обду́ван, о́блес, пашњака́m, тега́ран, тр́бан, тр́бат, трбуља́с, трбуља́m, троуша́н, тупана́с, тупа́нес, ши́шкав, шке́мбав, шкемба́c, шкемба́m, шће́мбав, шће́мбас, шћембám, поред семе високог ранга 'угојен', која је интегралног карактера, појављују се допунске компоненте које модификују садржај у неколико значењских праваца - 'низак', 'здепаст', 'великог стомака' и импликациона сема 'похлепан на јело', на основу којих се формира слика типичног дебелог становника југоисточне Србије (онизак, здепаст, израженог стомака, прождрљив). У непосредној значењској вези са дебљином је ниски раст: гма́чес, гме́чав, гме́чес, де́гмечас, дозе́мчес, зде́пас, трупеља́с, трупу́љес, изе́мчес, пуу́пав..., непожељна особина са приметном вербалном интерпретацијом. Поред реализације идентификационог семантичког знака 'који има малу висину': ни́сак, ма́јиак, маљозе́с, озе́мчес, о́малечак, чу́чук, кратконо́zас, кратконо́ђес..., конституенти овога реда делом семантичке структуре задиру с једне стране у сферу прекомерне ухрањености, а са друге у домен телесне слабости (ма́лецььк, ма́нечьк, гр́zaв, sṕsaв...), чиме се број квалификатива у овој категорији повећава, што додатно учвршћује њену позицију на скали најнепожељнијих физичких особина. Најнеповољнији естетски утисак оставља ониска и подебела, здепаста мушка особа, с обзиром на број и експресивност лексичких варијетета којима се именује: алча́к, ге́иа, др́доњак, жа́ба, жво́њьк, ке́nа, кепе́и, кукенде́р,

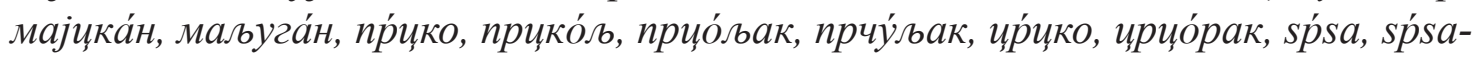
ващ, sṕsoљaк, ś́sмaн, sṕsaвко... Негативној аксиолошкој процени прекомерно ухрањених особа првенствено доприноси схватање односа према храни, које се као потенцијална компонента актуелизира на конотативном макроплану. Објективне негативне семе 'похлепан на јело', 'прождрљив', 'незасит', 'грамзив' присутне су у семантичком језгру придева а́ведан, а́ветан, а́лав, алотр́бан, др́чан, дрчљи́в, е́шан, једноцре́в, је́шан, неза́ситан, ненаје́див, рабан, ла́чан, ла́чоран, алобиттан, алау́nав, а́мишан, гра́бив, малкосве́тан. Инваријантно значење 'халапљив' пуни се експресивно-емотивним елементима, који у семантику придева уносе строги колективни суд и изразито негативну оцену. Да говорници призренско-тимочке дијалекатске области имају изузетно презрив однос према означеној карактерној црти, сведочи заступљеност синонимских редова 'халапљив човек' и 'халапљива жена' међу првих петнаест многочланих редова у категоријама мушке и женске номинације: аве́дник, авети́ға, áла, ала́пљивац, алапљи́вко, алоси́ја, алоси́на, алоби́тник, ву́рча, гладни́к, гње́тла, досреди́ја, др́ияо, 
др́чко, др́чља, дрчљи́вко, др́чник, дрчногу́з, Ђувеча́р, Ђувечли́ја, е́лаи, е́шник, изе́дица, изе́лица, изе́иа, изе́шник, је́шко, јешни́к, капсому́н, ла́комштина, ла́мза, ла́мча, ла́пало, ло́кман, локманци́ја, локма́ш, незаси́тник, незаси́тьак... / аведни́ца, авети́на, а́ла, алапљиви́йа, алама́нка, алобитни́ияа, гње́тла, др́чна, дрчљи́вка, др́чна, дрчни́ца, дрчногу́за, ешни́йа, жва́кла, жва́кна, жваку́ља, изе́дийа, изе́лица, изе́шница, ла́комица, локмании́ка, макулци́ка, незаситни́ща, обицоо́јка, обичо́јла, про́тура, тамаћа́рка... Погрдна именовања језички манифестују наглашени презир говорне заједнице према особама које много једу, као и према похлепи сваке врсте. Нарочито је упечатљив однос према јелу, кроз који се испољавају и друге карактерне црте - неконтролисаност нагона, склоност претеривању, хедонизам, себичност, необазривост према другима, што је у супротности са традиционалним и религиозним моралним начелима.

Фрагмент дијалекатске језичке слике света југоисточних српских говора који се односи на репрезентацију концепта телесности доминантно попуњавају лексичке варијанте експресивног садржаја, у којем је одражен нетолерантан однос заједнице према физички слабим лицима. Креативност језичке личности, која се огледа у формирању великог броја синонима пејоративног садржаја у домену квалификације слабог телесног састава, мотивисана је презривим односом колектива према појединцима неспособним за рад, према онима који нису у стању да доприносе заједничком напретку и који ремете нормалан ток друштвеног живота. Истим ставом може се објаснити потреба говорника да бројним именима исте намере маркира особу са телесним недостатком: богаљи́в, ва́личан, маани́m, ма́нит, манљи́в, слу́тан, насл́утен, фа́личан, не́способан, осака́ћен, а́лнут, а́лтав, а́нтив, бележи́m, сапетљи́в, сапетњи́чав, тро́шан, ује́ден, у́јет, у́лав, уло́гав, улога́вен, ча́лнут, че́љав, чóљ, чо́љав, чурукљи́в..., при чему је народ нарочито нетрпељив према хромим особама: кри́в, ба́нгав, богаљи́в, ге́гав, ге́нгав, кља́кав, кље́кав, па́трав, ћо́пав, а́ндрав, кривоно́г, кривоно́гас, једнокл́кав, багаљи́в, врљоно́г, ке́чав, кле́кав, кле́иав, кли́пав, ко́ндав, кривоклк, па́травшьк, ша́јес, ша́нтрав, ша́нтав, ша́трав, ше́пав, чута́к / багаљи́вча, кља́каваи, кљака́вштина, крива́к, кривенде́љ, кри́вља, кривокл́коња, кра́вча, кри́вща, ћónа, ћопа́вко, ћо́павштина, ћопенди́л, ћо́пко, ћо́пља, ћónча, ћónша... / ге́гла, ге́гна, кли́мка, кља́кавштина, кри́вка, кри́вла, кри́вна, кривокри́вка, па́травица, патра́вка, па́травштина... Бројност ознака којима се хром човек квалификује и именује показује да носиоци призренско-тимочких говора дефект хода сматрају најупечатљивијим телесним деформитетом. Није занемарљив ни број номинација за особе са говорном маном, а та језичка чињеница доприноси разумевању наивне концептуализације човека пре свега као социјалног бића, које се друштвено реализује првенствено посредством говора. Биолошки фактори који умањују квалитет међуљудских интеракција и отежавају вршење друштвених улога у средишту су колективне перцепције, а појединци са оштећењем говора и вербално су обележени бројним експресивима: б́ъћаваи, ь́ъћало, бр́бало, е́икоња, зае́ико, заеико́ја, је́икало, је́икоња, му́та, му́тавац, њу́ғьа, њу́ғало, шељука́н, шепеља́н, шепе́љћа, шовеља́н, шопе́љка, шо́шкало, шо́шка... / бъћавииа, вр́скавица, му́тна, му́тла, њу́ъавка, 
шупе́љка, шупеља́на, шу́шљавка, шу́шна, шушуле́јка, шу́шућа... С друге стране, припаднике југоисточних српских говора иритира претерана говорљивост, што провоцира њихову језичку креативност, која до изражаја долази у сва три домена категоризације, у лексичким ознакама које појмовно и семантички обједињују неке од елемената 'онај', 'који', 'много прича', 'празно прича', 'лупета', 'трабуња', 'оговара', 'трачари', 'гунђа': алапа́чес, алапа́јес, алапарљи́в, брбљи́в, вревљи́в, галатљи́в, гу́њгав, езича́т, за́орљив, језича́в, језича́т, лављи́в, ла́пав, ло́мотан, љо́пав, мла́тав, пь́нђав, ча́трав, цаврљи́в, цеврља́m / ьрматали́ја, бр́бљало, баље́згало, ба́мбало, бамбућа́ло, ба́нђало, банђука́ло, банђу́р, бантр́љало, блебета́ло, бр́бља, бр́бљавац, бр́бљавштина, брботљи́вко, бр́нбало, ву́ждало, дрдора́н, др́ндало, др́нкало, за́пљес, заковрда́н, закрко́ја, закриа́ло, клопота́ло, клопота́р, крекета́ло, лапр́дало, лапрда́н, млати́на, млати́шума, оратии́ја, оратли́ја, ора́тник, пља́ка, пља́кало, пља́мпало, пља́мпачија, пља́скало, тра́ъћало, тро́пало, чекета́ло, чекета́р, ца́вкало, цаврли́ја, цандрљи́вко, цва́ғгало ... / авлија́рка, алапа́јка, алала́јка, алава́јда, алапарљиви́ияа, алапа́ча, алапр́да, брбљиви́иа, вужда́љка, галамии́ка, галатљи́вка, галатни́ща, глтни́жаба, дрдора'на, др́нда, езича́на, езича́ра, езича́рка, решета́рка, секеле́рка, секле́рка, трчила́шка, чекета́рка, цавга́рка, цанђери́ияа... Интересантно је да је синонимски ред са дистинктивним знаком 'мушка особа' далеко бројнији у односу на женске номинације, а оваква дистрибуција номинација резултат је стереотипног уверења да је брбљивост карактеристика жена. Мушкарац са таквом особином нарочито је подложан омаловажавању и подсмеху, па отуда велики број погрдних ознака високог афективног тоналитета.

Одлике карактера које дијалекатска језичка личност оштро осуђује јесу лицемерје, превара, лаж, превртљивост, подмуклост, препредењаштво, оговарање, а лица која региструје као носиоце ових особина језички маркира мноштвом синонима афективног садржаја, који се у негативном номинационом пољу препознају по интегрално-диференцијалном семантичком знаку 'непоуздана особа': алава́јда, алава́нта, алаву́жда, газиве́ринац, вртика́јиฺа, врти́pеn, вртолома, врдалама́, вр́дало, врдола́ш, врдоља́к, дуни́ветар, ебиве́тар, ебиве́троња, еше́к, кули́за, кулиза́н, кулиза́нко, кули́зица, кускунии́ја, преврто́ја, преврто́тина.. / ль́жла, льжнна, льжоса́на, мазну́љћа, палаву́рда, палама́рка, пошушњápa, пошушњáрка... У језгру концептосфере негативних унутрашњих особина налазе се и поквареност, безосећајност, безобзирност, мржња, завидност, подлост, повређивање других, што се на дијалекатској језичкој слици света манифестује синонимским редовима чији чланови комбинују ове елементе и језички репрезентују носиоце ових особина, са инваријантним значењским обележјем 'зла особа': а́ла, алоси́на, алаво́тина, алаву́жда, але́тина, га́д, га́деж, гади́на, гадоси́ја, гадури́ја, гадури́на, кансь́р, катиља́к, ло́шља, лошоти́ја, ни́штавац, ништа́вко, ни́штак, ништачи́на, ни́штачове́к... / вадоду́шница, вапиру́ља, вештега́рка, ве́штица, гадури́ја, гадури́на, оштроко́ниа, оштроко́ниула, па́косница, пакошчи́ка... Етичке вредности говорне заједнице ишчитавају се управо преко негативних номинација из сфере моралности, јер оне најупечатљи- 
вије и најсликовитије рефлектују друштвено неприхватљиве црте карактера, а самим тим истичу оно што је пожељно са становишта општеприхваћеног морално-понашајног обрасца, на основу чега је могуће реконструисати карактерни профил прототипичне личности са југоистока Србије. Лексичко-семантички састав репрезената најбројнијег синонимског реда у категорији именовања женских особа одражава традиционално поимање женског морала и владајуће норме у том домену: бесрами́ља, ва́ћкалица, вли́нта, врајлети́на, вртире́пка, вуксети́на, вуциа́ра, ву́ила, дро́љна, дро́ца, курве́штија, курве́штина, курво́љина, ку́рка, ку́рла, нажмику́ља... Називи за бесрамну жену интегришу идеографске предзнаке 'морална посрнулост, сексуалност, безобразлук, блуд, разврат', који укључују компоненту објективне оцене 'то је лоше' и низ конотативних сема које експресивно и емотивно интензивирају денотативно значење. На аксиолошком значењском плану актуелизира се сема субјективне оцене којом је исказан колективни суд, и у тим сегментима семантичке структуре фиксиране су специфичности менталитета носилаца говора и утиснути кодови локалне културе.

Један од базних концепата у наивном сазнању дијалекатске језичке личности и један од кључних за разумевање менталитета као специфичног односа према свету и животу јесте однос према раду, о чему сведочи богат лексички репертоар који реализује значење 'лења особа': алама́н, алоби́тан, алоби́тник, алоси́ја, алоси́на, бадаваџи́ја, бађава́шник, бађавийја, бизго́вчина, би́щман, дебелде́р, де́мба, дембеде́љ, дембе́л, залудња́р, калпаза́н, ладавинича́р, локма́ш, труто́в, труто́вчина, цабали́ја, цабалеба́рош, цабале́боња... / бађавсе́дница, бађавциика, биима́нка, гње́тла, гње́ила, готова́нка, залу́дничарка, ле́њка, лењогу́за, лењче́рка, леъчуга́рка... Номинационе јединице које на наивној језичкој слици света попуњавају овај сегмент објективне стварност садрже представе социјума о раду, који се конципира као основна социјална и морална вредност, и изразито негативан став носилаца дијалекта према лењим људима. Лексичка продуктивност израженија је у категорији номинације мушких особа, а такав језички резутат указује на друштвено пожељни модел радно активног мушкарца, који је стуб породице и друштва. Вредан човек се намеће као прототипичан представник колектива, што подржава традиционалну представу о подели улога, где је дужност мушкарца да обезбеђује материјална средства и осигура финансијску стабилност породице. У том смислу, није изненађујуће што се у руралној средини вреднују способни појединци који добро зарађују, а маргинализују неспособни, нерадни и сиромашни. Погрдним називима којима су етикетирани сиромаси интерпретирано је схватање заједнице да сиромашни појединци нису пожељни чланови друштва, да се колектив према њима односи са омаловажавањем и прекором, jep је економска сигурност општи интерес социјума и један од његових приоритетних циљева: батакии́ја, бездина́ровић, бо́жјак, бу́јер, голеди́ја, голишта́р, гологуза́н, гологу́зоња, голои́гра, голоко́тра, голоши́ја, го́лча, го́љча, гољб́к, го́љча, гула́мфер, нема́ч, сиромá, сирома́чич, сле́nац... Народ, с друге стране, јавно процењује и оцењује однос имућних према сопственом новцу и изражава свој негативни суд према тврдицама, именујући их богатим пејоративним реперто- 
аром: гъгри́иа, гъњга́ч, драмсб́з, јагури́иа, несвидљи́вко, несвидљи́вча, скр́жа, скр́жаваи, скр́жљља, скр́чља, скрчо́тина, сти́nса, стипса́р, стипсогу́за, стипсо́љ, стиско́љ...

Пресек првих петнаест најбројнијих синонимских редова у категоријама квалификације и номинације мушких и женских лица у говорима југоисточне Србије потврђује тенденцију дијалекатске језичке личности да вербално обележи негативне људске особине, при чему се уочава доминација непожељних духовних особина у односу на телесне и тежња да се носиоци таквих унутрашњих карактеристика маркирају што већим бројем лексичких варијаната. Многобројни синонимски редови у домену унутрашње карактеризације личности истичу актуелни интерес припадника југоисточних српских говора за оне људске особине које су суштински важне за просперитет заједнице и друштвену интеракцију. У говору су истакнуте морално-карактерне црте појединаца које умањују квалитет међуљудских односа, а то су обест, непоузданост, злоба, склоност претераном говорењу. Социјалну стабилност заједнице, нарочито породице, разара бешчашће жена, и такве су жене изложене јавном руглу и маркиране најпогрднијим називима. Народ региструје менталне и телесне црте које онемогућавају идивидуи да реализује очекиване улоге или је ометају да се као равноправни члан интегрише у заједницу, при чему не исказује емпатију према носиоцима таквих унутрашњих и спољашњих карактеристика, већ их вербално етикетира пејоративима високог степена експресивности и тиме потпуно изопштава из функционалног друштвеног оквира. Многочлани синонимски редови профилишу друштвено пожељну слику човека, која је архетипски утиснута у свести човека са југоистока Србије као прототип у односу на који се припадници говорне заједнице процењују. За представнике југоисточних српских говора прототипичан мушкарац је интелигентан, радан, психички стабилан и поштен, а прототипична жена је честита, уредна, мудра и вредна. Приметна је квантитативна доминација негативних мушких номинација, чији узрок, највероватније, лежи у подели улога и чињеници да су у традиционалном друштву и руралним срединама мушкарци друштвено активнији, а самим тим су и њихове карактеристике транспарентније и изложене јавном суду.

Укупна статистика негативних вербалних репрезентација показује да пет најбројнијих синонимских редова садржи следећа идентификациона семантичка обележја: 'глуп ' (257 лексичких ознака), 'лењ' (173), 'неуредан' (168), 'брбљив' (151), 'непоуздан' (133). Семантичке карактеристике многочланих синонимских редова садрже негативне асоцијације, на основу којих се може реконструисати прототипичан профил становника југоисточне Србије. На самом врху вредносне скале је ментално здравље, затим спремност на рад и уредност. Народ са овог подручја изнад свега цени бистар ум и пристојан, уредан спољашњи изглед, који је у вези и са менталним развојем и са радним активостима човека. Специфичне лингвокултурне црте ове говорне зоне манифестују се у микросистему именовања халапљивих особа, где до изражаја долази презрив однос колектива према похлепи сваке врсте. Источносрбијанском менталитету иритантна је претерана 
говорљивост, посебно код мушких лица. У говору су истакнуте интелектуалне и морално-карактерне црте појединаца које умањују квалитет међуљудских односа и нарушавају социјалну стабилност породице и заједнице, а то су лудост, глупост, бестидност, обест, непоузданост, злоба, тврдоглавост. Народ, такође, перципира и вербално маркира она телесна својства које су концептуално најчешће у вези са здрављем, а која отежавају или онемогућавају појединцу да реализује очекиване друштвене улоге. Бројчани подаци показују да су хромост (118 лексема) и неухрањеност (96) најнепожељније спољашње карактеристике.

Логичка повезаност која постоји међу појавама из објективне стварности пресликава се на значењску структуру ознака за поједине особине и носиоце датих особина, тако да су парадигматски односи унутар лексичког система детерминисани изванјезичким факторима. Најбројнији синонимски редови у лексичко-семантичком систему говора југоисточне Србије предочавају логичку и системску повезаност изванјезичких појава и репрезентују начин на који говорници ове дијалекатске зоне концептуализују свет око себе. Рангираност синонимских редова пружа увид у модел категоризације објективне стварности и у систем вредности становника са овога терена, тако да се може поуздано уочити које су то људске особине посебно значајне и шта се у народу перципира као важно, како за индивидуално, тако и за опште добро. Распоред синонимских редова одаје тенденције у схватању света и човека, које носе лингвокултурни печат овог ареала. Синонимски ред, као најужа семантичка група у оквиру лексичко-семантичке парадигме, најиздиференцираније, најпрецизније и најефектније описују човека, сликовито дочарава варијантни потенцијал народних говора и предочава способност дијалекатске језичке личности да шароликим дијапазоном језичких средстава нагласи значењске нијансе и да пронађе адекватне механизме како би лексичким синонимом постигла потпуни семантички и прагматички ефекат. ${ }^{3}$ Процес формирања синонимских редова у народним говорима почива на моделима творбене и семантичке деривације, укључујући сликовито и емотивно преосмишљавање реалности и компоненте традиционалне културе колектива и његов наивни поглед на свет.

${ }^{3}$ „В МСР (многочисленные синонимические ряды, прим. аут.) обнаруживаются и воплощаются как частные денотативные и сигнафикативные различия, так и коннотативные различия синонимов, т. е. человек представлен в максимуме оттеночных, дифференцирующих его ипостаси смыслов. МСР позволяют выделить в образе человека тонкие оттенки, которые не всегда актуализируются в речи, но само их существование и возможность актуализации делают многочленную синонимику самым зффективным инструментом описания человека с наибольшим вниманием к тонкостям, деталям” (Покровская 2008: 8). 


\title{
ЛИТЕРАТУРА
}

Богдановић 2016: Н. Богдановић, Антропографски речник југоисточне Србије, СДЗБ LXIII, Београд, 1-276.

Покровская 2008: О. В. Покровская, Языковой образ человека в синонимических репрезентациях: опыт разработки частной теории (на материале русского и английского языков), Афторефереат диссертации, <http://www.dissercat. $\mathrm{com} /$ content/yazykovoi-obraz-cheloveka-v-sinonimicheskikh-reprezentatsiyakhopyt-razrabotki-chastnoi-teor\#ixzz4yaHZOfOJ> 8. 11. 2017.

Хисамова-Хисматуллина 2016: В. Н. Хисамова, Л. Г. Хисматуллина, Синонимические репрезентации физиологических состояний человека в татарском и английском языках, Научный диалог, № 4 (52), http://nauka-dialog.ru/arxiv/2016/ nauchnyij-dialog-2016-4-52/, 8. 11. 2017.

Tanja Z. Milosavljević

\section{SYNONYMIC CHAINS AS AN EXPRESSION OF THE LINGUO-CULTURAL SPECIFICITIES OF THE DIALECTS OF THE LEXICAL SYSTEM}

\author{
Summary
}

The topic of this paper are synonymic chains as a means of representing the linguistic image of man and a reflection of the linguo-cultural specificities of a dialectical lexical system. By means of a cognitive-semantic and linguo-cultural analysis of multi-part synonymic chains from the anthropographic lexis of the Prizren-Timok dialect region, we will evaluate the way in which synonymic chains reflect specific linguistic and cultural features as well as the mentality of the dialectical personality and its views of the world. The material used in the study was taken from the Anthropographic dictionary of South-East Serbia (Bogdanović 2016). The overall statistics of negative verbal representations indicate that five of the most numerous synonymic chains contain the following semantic features: 'stupid' (257 lexical features), 'lazy' (173), 'untidy' (168), 'talkative' (151), 'unreliable' (133). At the very tip of this value scale we find mental health, and then the willingness to work and be neat. Numerous synonymic chains in the domain of internal characterization of a person indicate the current interest of the members of South-East Serbian speech for those human features which are of essential importance for the prosperity of a community and social interaction. Multi-part synonymic chains profile a socially desirable image of a man from South-East Serbia as the prototype which against which 
the members of a speech community are evaluated. For the representatives of the South-East Serbian speeches, the prototypical male is intelligent, hard-working, psychologically stable and honest, and the prototypical woman is pure, neat, wise and diligent.

Key words: synonymic chain, linguo-cultural specificities, the Prizren-Timok dialect region. 